\title{
Performance of high yielding drought tolerant varieties of maize and in situ moisture conservation techniques in Kandi region of Punjab, India
}

\author{
Vijay Kumar*, Vivek Sharma, S. C. Sharma and Sukhvinder Singh \\ Regional Research Station for Kandi Area (Punjab Agricultural University), Ballowal Saunkhri, Balachaur, SBS \\ Nagar- 144521 (Punjab), INDIA \\ *Corresponding author. E-mail: vijaypau@pau.edu
}

Received: July 5, 2016; Revised received: October 26, 2016; Accepted: January 30, 2017

\begin{abstract}
In the present investigation, 87 front line demonstrations (FLDs) of maize were conducted on farmers' fields to demonstrate the impact of high yielding drought tolerant varieties (JH 3459, Parkash and PMH 1) and in situ moisture conservation techniques (ridge sowing, sowing across the slope, summer ploughing and earthing up) on production and economic benefits in Kandi region of Punjab state during kharif seasons from 2011 to 2013 under rainfed situation. The improved production technologies recorded additional yield ranging from 29.7 to $47.6 \mathrm{q} / \mathrm{ha}$ with a mean yield of $37.1 \mathrm{q} / \mathrm{ha}$ and 24.4 to $42.6 \mathrm{q} / \mathrm{ha}$ with a mean yield of $32.7 \mathrm{q} / \mathrm{ha}$ for drought tolerant varieties and in situ moisture conservation techniques, respectively. The per cent average increase in yield of drought tolerant varieties over local cultivars was 35.8 , while 15.6 for in situ moisture conservation techniques. The average extension gap, technology gap and technology index were $9.8 \& 4.4 \mathrm{q} / \mathrm{ha}, 3.7 \& 6.1 \mathrm{q} / \mathrm{ha}$ and $9.1 \& 16.7$ per cent, respectively in drought tolerant varieties and in situ moisture conservation techniques. FLDs recorded higher mean net returns i.e. Rs. 36,292 and 28,234 per ha. with $B: C$ ratio of 2.53 and 2.17 for drought tolerant varieties and in situ moisture conservation techniques, respectively. The FLDS conducted revealed that availability of suitable high yielding variety and lack of knowledge about improved production technologies is the main bottleneck in maize production, enhancement of yield and knowledge of the farmers. Hence, the productivity of maize can be increased by adoption of the recommended management practices and the study resulted in convincing the farming community about potentialities of the recommended production technologies in yield enhancement.
\end{abstract}

Keywords: FLDs, Improved Technologies, In situ Moisture Conservation, Maize

\section{INTRODUCTION}

Maize (Zea mays L.) is the most important world's leading cereal crop having wider adaptability under varied agro-climatic conditions. Globally, maize is known as queen of cereals because it has the highest genetic yield potential among the cereals. It is cultivated in about 160 countries having wider diversity of soil, climate, biodiversity and management practices. During 2013, globally it was cultivated on an area of $185.1 \mathrm{~m}$ ha with production of $1018.1 \mathrm{~m}$ tonnes (FAO, 2013). In India, maize is the third most important food crops after rice and wheat and is being cultivated on $9.5 \mathrm{~m}$ ha with 80 per cent area during kharif season. The current maize production in India is $23.3 \mathrm{mt}$ with an average productivity of $24.5 \mathrm{q} /$ ha which is less than half of world productivity (54.9 q/ha). In Punjab, it is grown on $0.13 \mathrm{~m}$ ha area with production of $0.48 \mathrm{~m}$ ton and productivity of $36.8 \mathrm{q} /$ ha (Anonymous, 2013). The sub-mountainous region in the North-Eastern part of Punjab in the form of a 10 to $20 \mathrm{~km}$ wide strip immediately next to Shiwalik hills is known as 'Kandi'. The area of kandi region is approx. 3.93 lakh hectares which comprises approximately 7.8 per cent of total geographical area of the State. This zone is located between $30^{\circ} 44^{\prime}$ and $32^{\circ} 32^{\prime} \mathrm{N}$ latitude and $75^{\circ} 52^{\prime}$ and $76^{\circ} 43^{\prime} \mathrm{E}$ longitude at an elevation of $300-$ $500 \mathrm{~m}$ above mean sea level. The productivity of maize is lower as compared to average state productivity in this region due to cultivation of the crop under rainfed conditions as well as poor knowledge about drought tolerant varieties \&production. The productivity of maize per unit area could be increased by adopting recommended scientific and sustainable management production practices using suitable high yielding varieties (Dhaka et al., 2010 and Ranawat et al., 2011). Frontline demonstration is the new concept of field demonstration evolved by the Indian Council of Agriculture Research (ICAR) with main objective to demonstrate newly released crops, production and protection technologies and its management practices in the farmers' fields under different farming situations \&different agro-climatic regions of the country. While demonstrating the technologies in the farmer's fields, the main objective is to study the factors contributing higher crop production, field constraints of production and thereby generate production data and feedback 
information. Keeping all above into considerations, frontline demonstrations on maize (on farmer's fields) were conducted to demonstrate the production potential and economic benefits of recently developed varieties (drought tolerant\& high yielding) and in situ moisture conservation techniques to the farmers and convincing the farmers to adopt the improved production technologies of maize.

\section{MATERIALS AND METHODS}

A total of eighty seven frontline demonstrations (FLDs) were conducted during Kharif season from 2011- 2013 on farmers' fields under rainfed conditions in villages such as Naude Majra, Rajgiri, Jhandian, Jatawar, Dhamana (Distt. Rupnagar), Achalpur and Nainwan (Distt. Hoshiarpur) of Punjab to demonstrate the effect of high yielding drought tolerant maize hybrids and in situ moisture conservation techniques on the productivity of maize. The soils of the farmer fields were coarse to medium in texture, neutral to slightly saline in reaction, low in organic carbon and available nitrogen and medium to high in available phosphorus \& potassium. Each demonstration was conducted on an area of 0.1 to 0.2 ha and adjacent plot to the demonstration plot was kept as farmers practices.

To popularize the improved maize production practices, constraints in maize production were identified though participatory approach. Preferential ranking technique was utilized to identify the constraints faced by the respondent farmers in maize production. Farmers were also asked to rank the constraints they perceive as limiting factor for maize cultivation in order of preference. Based on top rank farmers problems identified, front line demonstrations were planned and conducted at the farmer's fields. The improved technologies selected for FLDs were improved high yielding drought tolerant varieties and different in situ moisture conservation techniques (Table 1). The other management practices like seed treatment, maintenance of optimum plant stand, recommended fertilizers dose and plant protection etc. were applied for improved as well as farmer practice and they only differed for either variety or in situ moisture conservation technique as per FLD. The demonstrations were sown in last week of June to second week of July during the three years with the seed rate of $20 \mathrm{~kg} / \mathrm{ha}$ and spacing of $0.45 \mathrm{~m} \mathrm{x} 0.25$ m.All the crop management practices as per the package of practices for Kharif crops by Punjab Agricultural University, Ludhiana were followed for raising the crop. The yield attributing traits like number of cobs/100 plants, cob length $(\mathrm{cm})$ and cob girth $(\mathrm{cm})$ were taken from average of ten cobs and shelling percentage were recorded and compared with local variety in case of FLDs on drought tolerant varieties, while production and economic data was recorded and analysed for all FLDs and local practices.
The average of the individual improved/ local practice for the three years has been taken for interpretation of the results.

Shelling $\%=$ (Grain weight after shelling/dry weight of the cobs) $\mathrm{x} 100$

The extension gap, technology gap and technology index were calculated using the formula as suggested by Samui et al. (2000).

Extension gap $(\mathrm{q} / \mathrm{ha})=$ Demonstration yield $(\mathrm{q} / \mathrm{ha})-$ Yield of improved technology (q/ha).

Technology gap $(\mathrm{q} / \mathrm{ha})=$ Potential yield $(\mathrm{q} / \mathrm{ha})-$ Demonstration yield (q/ha).

Technology index $(\%)=\{$ Potential yield - Demonstration yield) / Potential yield $\} \times 100$

Knowledge level of the farmers about improved production practices of maize before frontline demonstration implementation and after implementation was measured and compared by applying paired t-test at 5 per cent level of significance.

\section{RESULTS AND DISCUSSION}

Constraints in maize production: Problems faced by the farmer's in maize cultivation were documented during the study. Preferential ranking technique was utilized to identify the constraints faced by the respondent farmers in maize production and rankings given by the farmers to different constraints are given in Table 2. A perusal of table indicates that availability of suitable high yielding variety (HYV) seed ( $82 \%)$ was given the top most rank followed by low technical knowledge (74\%), wild animal damage (70\%), and uncertainty of monsoon rains/drought $(68 \%)$ were the major constraints to maize production. Other constraints such as stem borer infestation, weed infestation, water lodging and post harvest management were also found to reduce maize production. Dhruw et al.(2012), Sreelakshmi et al.(2012) and Meena et al. (2014), Kumar et al. (2015) and Sharma et al. (2016) have also reported similar problems in maize and other crops and the results also indicated similar constraints in maize production.

Increase in knowledge: The knowledge level of the farmers on various aspects of improved production technologies in maize increased by 26.50 after implementation of frontline demonstrations (Table 3). As the computed value of 't-test' (9.32) was statistically significant at $5 \%$ probability level. In other words there was significant increase in knowledge level of the farmers due to frontline demonstration. The results of the present study are at par with the reports of Singh and Sharma (2004) on mustard crop, Malik et al. (2005) and Dhaka et al. (2010) on maize crop and Sharma et al. (2016) on wheat crop who also reported increase in knowledge through FLDs. This shows positive impact of frontline demonstration on knowledge of the farmers that have resulted in higher adoption of improved farm practices. 
Vijay Kumar et al. / J. Appl. \& Nat. Sci. 9 (1): $316-323$ (2017)

Table 1. Particulars showing the details of maize growing under FLD and farmer practices.

\begin{tabular}{|c|c|c|c|}
\hline S. No. & Technology & Farmers Practice & Improved practices \\
\hline 1 & Variety & $\begin{array}{ll}\text { Local/unknown } & \text { variety } \\
\text { from local market } & \end{array}$ & Drought tolerant varieties JH 3459, Parkash, PMH 1 \\
\hline 2 & Spacing & Broadcasting of seed & $\begin{array}{l}\text { Line sowing with spacing of } 45 \mathrm{~cm} \text { between rows and } \\
25 \mathrm{~cm} \text { between plants in the row. }\end{array}$ \\
\hline 3 & Seed rate & $25-30 \mathrm{~kg} / \mathrm{ha}$ & $20 \mathrm{~kg} / \mathrm{ha}$ \\
\hline 4 & $\begin{array}{l}\text { Summer } \\
\text { ploughing }\end{array}$ & $\begin{array}{l}\text { Most of the farmers don't } \\
\text { open the fields in the } \\
\text { month of June. }\end{array}$ & $\begin{array}{l}\text { Fields were ploughed in the month of June before on- } \\
\text { set of monsoon rains. It makes the field surface rough } \\
\text { and cloddy, exposes more surface area which helps in } \\
\text { increasing rainwater interception and more opportune } \\
\text { time to infiltrate, thereby improving soil moisture con- } \\
\text { tent and reducing runoff \& soil erosion. It helps to kill } \\
\text { weeds, hibernating insects and disease-causing organ- } \\
\text { isms by exposure to summer heat. }\end{array}$ \\
\hline 5 & Ridge sowing & $\begin{array}{l}\text { Sowing on flat bed with } \\
\text { broadcasting method }\end{array}$ & Sowing on ridges prepared with ridge maker. \\
\hline 6 & Earthing up & $\begin{array}{l}\text { Most of the farmers do not } \\
\text { perform this operation due } \\
\text { to either non availability of } \\
\text { labour or lack of } \\
\text { knowledge }\end{array}$ & $\begin{array}{l}\text { Earthing up is done in the after about one month of } \\
\text { sowing at knee height stage as it gives support to plant } \\
\text { as well as save from water logging. }\end{array}$ \\
\hline 7 & $\begin{array}{l}\text { Other crop } \\
\text { management \& } \\
\text { protection prac- } \\
\text { tices }\end{array}$ & $\begin{array}{l}\text { Farmers are cultivating } \\
\text { these crop without adop- } \\
\text { tion of any improved tech- } \\
\text { nology }\end{array}$ & $\begin{array}{l}\text { All the crop management practices as per the package } \\
\text { of practices for Kharifcrops by Punjab Agricultural } \\
\text { University, Ludhiana were followed for raising the } \\
\text { crop. }\end{array}$ \\
\hline
\end{tabular}

Table 2. Ranks given by farmers for different constraints $(\mathrm{n}=100)$.

\begin{tabular}{llcc}
\hline S. No. & Constraints Percentage Ranks & Percentage & Rank \\
\hline 1 & Availability of suitable HYV seed & 82 & I \\
2 & Stem borer infestation & 52 & V \\
3 & Low soil fertility & 30 & VIII \\
4 & Low technical knowledge & 74 & II \\
5 & Damage by wild animals & 70 & III \\
6 & Uncertainty of Monsoon/drought & 68 & IV \\
7 & Weed infestation & 35 & VI \\
8 & Water lodging & 33 & VII \\
9 & Post harvest management & 27 & IX \\
\hline
\end{tabular}

Table 3. Comparison between knowledge levels of the respondent farmers about improved management practices of maize $(n=50)$.

\begin{tabular}{cccc}
\hline & Mean score & Calculated 't' value \\
\hline Before FLD & After FLD & Mean difference & $9.32^{*}$ \\
\hline 42.50 & 69.0 & 26.50 & \\
\hline
\end{tabular}

Significant at $5 \%$ probability level

\section{Performance of frontline demonstrations}

Yield attributing traits: The average number of cobs per 100 plants in drought tolerant varieties was 121 in comparison to 98 in case of local cultivars and it ranged from 118 to 124 in drought tolerant varieties
(Table 4), while it ranged from 95 to 102 in local cultivars with average increase of 22.8 per cent over local cultivars. The cob length and cob girth was also more in case of drought tolerant varieties and it ranged from 15.8 to $16.7 \mathrm{~cm}$ and 11.8 to $13.5 \mathrm{~cm}$ with an average of 


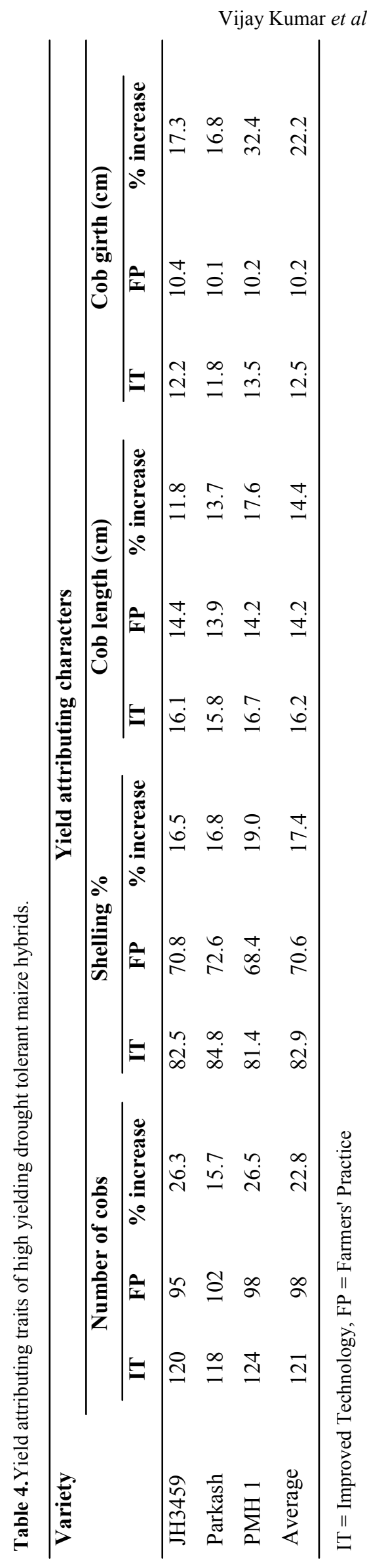

16.2 and $12.5 \mathrm{~cm}$, respectively. The average increase in cob length and cob girth was 14.4 and 22.2 per cent, respectively over the local cultivar. The shelling percentage ranged from 81.4 to 84.8 with an average of 82.9 in comparison to average value of 70.6 in local cultivars. The per cent increase in shelling percentage over local cultivars was 17.4. These results showed significant increase in the yield attributing traits in case of drought tolerant varieties. The yield of the farmers' field is on the lower side because they are still using local / unknown cultivars due to non-availability of the quality maize seed or due to higher price of the hybrid seed available in the market. Yield: It was observed that the productivity of maize in the FLDs ranged between 29.7 to $47.6 \mathrm{q} / \mathrm{ha}$ and 24.4 to $42.6 \mathrm{q} / \mathrm{ha}$ with a mean yield 37.1 and $32.7 \mathrm{q} / \mathrm{ha}$ for drought tolerant varieties and in situ moisture conservation techniques, respectively (Table 5). The productivity under drought tolerant varieties varied from 30.0 to $44.4,29.7$ to 37.4 and 34.7 to $47.6 \mathrm{q} / \mathrm{ha}$ for the varieties JH 3459, Parkash and PMH 1, respectively as against the average yield of $27.4 \mathrm{q} / \mathrm{ha}$ for local cultivar even under improved management practices. However, productivity under different in situ moisture conservation techniques varied from 31.2 to $34.3,24.4$ to $42.1,30.0$ to 36.0 and 26.7 to $42.6 \mathrm{q} / \mathrm{ha}$ for the ridge sowing, summer ploughing, sowing across the slope and earthing up, respectively against the average yield range from 27.1 to 29.8 with a mean of $28.3 \mathrm{q} / \mathrm{ha}$ of farmer practices. The additional yield of different varieties over local cultivar ranged 5.2 to $13.5 \mathrm{q} / \mathrm{ha}$ with a mean of $9.8 \mathrm{q} / \mathrm{ha}$ in comparison to local varieties, while it ranged between 2.9 to $6.0 \mathrm{q} / \mathrm{ha}$ with a mean of $4.4 \mathrm{q} / \mathrm{ha}$ in comparison to farmer's practices for in situ moisture conservation techniques. The per cent increase in yield ranged from 18.8 to 49.4 and 10.2 to 22.1 with an average of 35.8 and 15.6 per cent, respectively for drought tolerant varieties and in situ moisture conservation techniques over farmer practices.

The variation in the productivity was caused by delay in sowing in some of the farmer's fields due to delayed onset of monsoon, prolonged dry spell during the growth period and variation in soil fertility in the farmer fields. Similar, enhancement in productivity of different crops through front line demonstration has been documented by Tiwari et al. (2003), Sreelakshmi et al. (2012), Meena et al.(2014), Kumar et al. (2014) and Sharma et al. (2016) and the FLDs conducted in the present investigation also resulted in enhanced productivity which is in line with the results of these workers. The results indicated that performance of improved varieties was better than the local cultivars and farmers were motivated by HYVs and improved technologies demonstrated in the FLDs which will result in adoption of these improved technologies.

Extension gap: Extension gap is the difference in the 
Vijay Kumar et al. / J. Appl. \& Nat. Sci. 9 (1): 316 - 323 (2017)

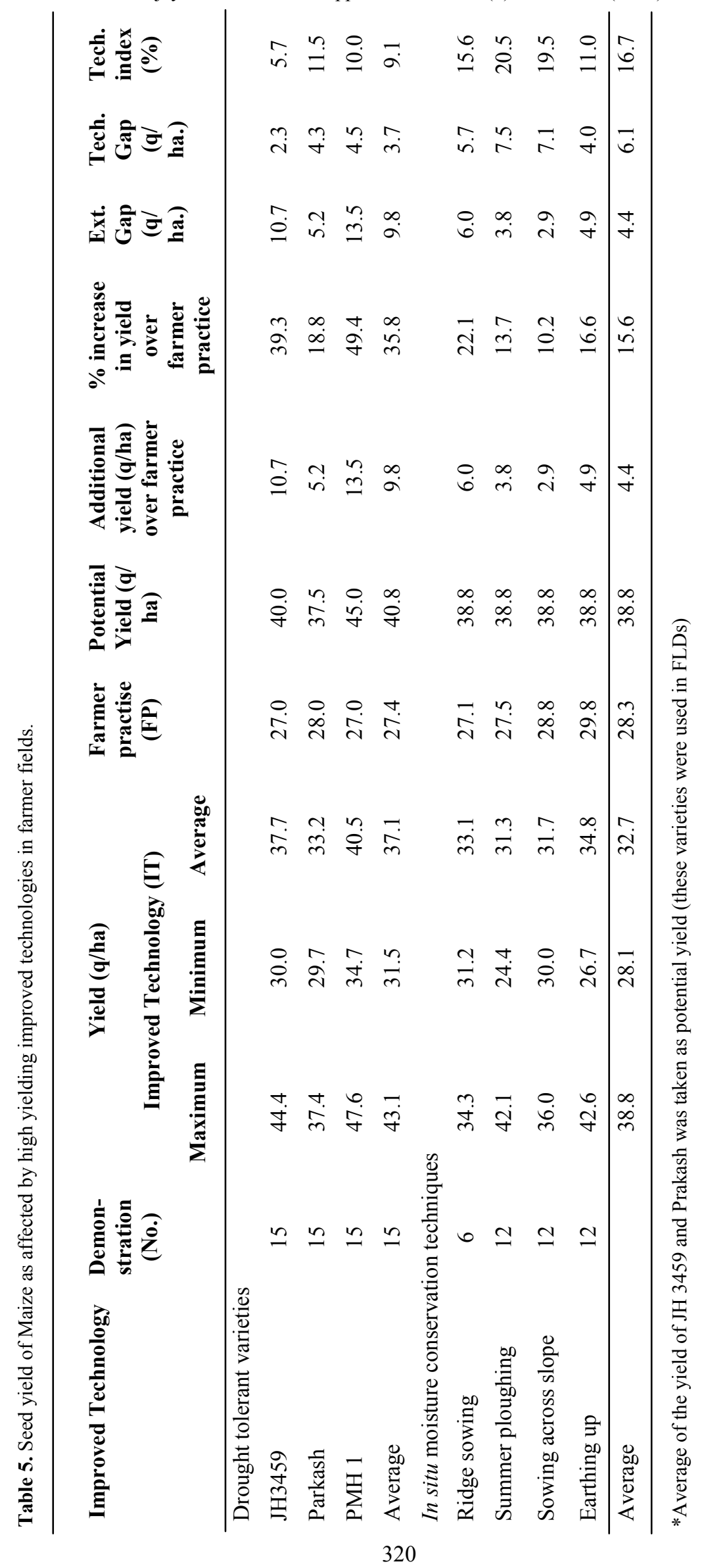


Table 6. Cost of cultivation (Rs/ha), net return (Rs/ha) and benefit: cost-ratio of Maize as affected by improved and farmer practices.

\begin{tabular}{|c|c|c|c|c|c|c|c|c|}
\hline \multirow[t]{2}{*}{ Technology } & \multicolumn{2}{|c|}{$\begin{array}{c}\text { Cost of cultivation } \\
\text { (Rs/ha) }\end{array}$} & \multicolumn{2}{|c|}{$\begin{array}{l}\text { Net returns } \\
\text { (Rs/ha) }\end{array}$} & \multirow{2}{*}{$\begin{array}{c}\text { Additional } \\
\text { cost of } \\
\text { cultivation } \\
\text { (Rs./ha) }\end{array}$} & \multirow{2}{*}{$\begin{array}{c}\text { Additional } \\
\text { net returns } \\
\text { (Rs./ha) }\end{array}$} & \multicolumn{2}{|c|}{ B:C Ratio } \\
\hline & IT & FP & IT & FP & & & IT & FP \\
\hline \multicolumn{9}{|c|}{ Drought tolerant varieties } \\
\hline JH3459 & 24121 & 21998 & 36722 & 24474 & 2124 & 12248 & 2.56 & 2.17 \\
\hline Parkash & 23754 & 21998 & 30600 & 24474 & 1757 & 6126 & 2.42 & 2.17 \\
\hline PMH 1 & 26259 & 21998 & 41554 & 24474 & 4261 & 17079 & 2.61 & 2.17 \\
\hline Average & 24711 & 21998 & 36292 & 24474 & 2714 & 11818 & 2.53 & 2.17 \\
\hline \multicolumn{9}{|c|}{ In situ moisture conservation techniques } \\
\hline Ridge sowing & 25033 & 24024 & 28994 & 20103 & 1008 & 8891 & 2.16 & 1.85 \\
\hline $\begin{array}{l}\text { Summer } \\
\text { ploughing }\end{array}$ & 23396 & 23086 & 24933 & 20000 & 310 & 4932 & 2.11 & 1.89 \\
\hline $\begin{array}{l}\text { Sowing across } \\
\text { slope }\end{array}$ & 23542 & 23348 & 25008 & 23191 & 194 & 1817 & 2.14 & 1.98 \\
\hline Earthing up & 26810 & 25210 & 34001 & 28701 & 1600 & 5300 & 2.26 & 2.08 \\
\hline Average & 24695 & 23917 & 28234 & 22999 & 778 & 5235 & 2.17 & 1.95 \\
\hline
\end{tabular}

yield of the demonstration and farmers practices. The value of extension gap (Table 5) varied from 5.2 to $13.5 \mathrm{q} /$ ha for drought tolerant varieties, $2.9 \mathrm{q} / \mathrm{ha}$ to 6.0 $\mathrm{q} /$ ha for in situ moisture conservation techniques with an average value of $9.8 \mathrm{q} / \mathrm{ha}$ and $4.4 \mathrm{q} / \mathrm{ha}$, respectively which may be due to non-availability of quality seed and inputs and lack of knowledge among farmers. Hence, to exploit the potential of improved production and protection technologies efforts through FLDs ought to be increased awareness among the farmers. It shows that the different extension agencies have to make hard efforts to technologically backing of the extension agency for the speedy transfer of the recommended technology to the farmers' fields. Further, the above extension gap emphasized the need to educate the farmers through various means for adoption of improved agricultural production technologies to reduce this extension gap. Increased use of latest production technologies with high yielding varieties will subsequently change the trends of extension gap which in turn would lead to higher productivity, farmers' income and prosperity.

Technology gap: The technology gap shows the gap in the demonstration yield over potential yield and it ranged between $2.3 \mathrm{q} / \mathrm{ha}$ to $4.5 \mathrm{q} / \mathrm{ha}$ with average of $3.7 \mathrm{q} / \mathrm{ha}$ for drought tolerant varieties (Table 5), while for in situ moisture conservation techniques it ranged between $4.0 \mathrm{q} / \mathrm{ha}$ to $7.5 \mathrm{q} / \mathrm{ha}$ with average of $6.1 \mathrm{q} / \mathrm{ha}$. The observed technology gap may be due dissimilarity in the soil fertility status, weather condition and other management practices (Tiwari et al., 2014 and Sharma et al., 2016). Hence variety-wise location specific recommendation with full package of practices and other pre-requisite appears to be necessary to minimize the technology gap for yield level under different situations. Such steps would boost up the production and bring more prosperity to the farming community.

Technology index: Technology index varied from 5.7 (JH 3459) to 11.5 (Parkash) per cent with average of 9.1 per cent for drought tolerant varieties (Table 5), whereas it varied from 11.0 (earthing up) to 20.5 (summer ploughing) per cent with average of 16.7 per cent for in situ moisture conservation techniques and showed the feasibility of the varieties as well as in situ moisture conservation techniques at the farmer's field. The lower the value of technology index more is the feasibility of the improved technology in the farmer's field as this indicated that technology is suitable for the particular region. The variation in yield from location to location can be accounted for varying climatic condition, prevailing microclimatic and variation in agricultural practices followed. The findings of the present study about extension gap, technology gap and technology index (\%) are in line with the findings of Dhaka et al. (2010), Meena et al. (2014) and Sharma et al. (2016).

Economics: The economic analysis of improved technologies over traditional farmer's practices was calculated depending on the prevailing market prices of inputs and outputs (Table 6). It was found that cost 
of production of maize under improved technologies varied from Rs. 24,121 to Rs. 26,259 and 23,396 to 26,810 with average of 24,711 and 24,695 for drought tolerant varieties and in situ moisture conservation techniques, respectively in comparison to average cost of production of Rs. 21,998 \& 23,917 for local practices. The additional cost incurred in the improved technologies was mainly due to more costs involved in the cost of improved seed and cultural practices involved in case of in situ moisture conservation techniques. FLDs recorded higher mean net returns i.e. Rs. 36,292 and 28,234 per ha with higher B:C ratio of 2.53 and 2.17 for drought tolerant varieties and in situ moisture conservation techniques, respectively. These results are in line with the findings of Hiremath and Nagaraju (2009) and Sreelakshmi et al. (2012) and Kumar et al. (2015) who also reported higher net returns and $\mathrm{B}: \mathrm{C}$ ratio in the FLDs compared to farmers' practices. Further, the average additional cost of Rs.2714 and 778 per ha has yielded additional net returns of Rs. 11,818 and 5,235 per ha in FLDs on drought tolerant varieties and in situ moisture conservation techniques, respectively suggesting higher profitability and economic viability of the FLDs which are in line with the results of Hiremath and Nagaraju (2009). The results from the present study clearly brought out the potential of improved production technologies in enhancing maize production and economic gains in rainfed farming situations.

\section{Conclusion}

FLDs conducted at the farmers' fields revealed that the adoption of improved production technologies significantly increased the yield as well as yield attributing traits of the crop and also the net returns. It can be observed that increased yield was due to adoption of high yielding varieties, in situ moisture conservation techniques and proven production technologies. So, there is need to disseminate the improved production technologies among the farmers with effective extension methods like training and demonstrations. The farmers should be encouraged to adopt the recommended package of practices for the crop for higher returns. The study reported lack of suitable high yielding drought tolerant maize varieties as major constraint by the beneficiaries and is ranked first followed by low technical knowledge, damage by wild and stray animals and uncertainty of monsoon/ drought. Hence, farmers should be encouraged to adopt the recommended package of practices for the crop for higher returns.

\section{ACKNOWLEDGEMENTS}

We sincerely thank all the farmers of different villages on whose fields' frontline demonstration were conducted. The financial assistance and technical support provided by All India Coordinated Research Project for Dryland Agriculture, National Initiative for Climate Resilient Agriculture (NICRA) and Directorate of Research, Punjab Agricultural University, Ludhiana is duly acknowledged. The views expressed in this paper are those of individual scientists and do not necessarily reflect the views of the donor or the authors' institution.

\section{REFERENCES}

Anonymous (2013). Statistical Abstracts of Punjab.http: // www. esopb. gov.in /static/PDF/ Statistical-Abstract2013.pdf

Dhaka, B.L., Meena, B.S. and Suwalka, R.L. (2010). Popularization of improved maize production technology through frontline demonstrations in south-eastern Rajasthan. J. Agril. Sci. 1(1):39-42.

Dhruw, K.S., Sengar, R.S. and Yadav, K.N. (2012). Level of knowledge and adoption about recommended maize production technology. Agril. Update 7(3\&4):311-315.

FAO. (2013). FAO Agricultural Production Statistics, http:// faostat3.fao.org/ as accessed on 17 April 2015.

Hiremath, S.M. and Nagaraju, M.V. (2009). Evaluation of front line demonstration trials on onion in Haveri district of Karnataka. Karnataka J. Agril. Sci. 22 (5):10921093

Kumar, V., Sharma, V. and Sharma, S.C. (2014). Impact of improved technologies on productivity enhancement of sesame (Sesamum indicum L.). Indian J. Dryland Agril. Res. \& Dev. 29(2): 41-44

Kumar, V., Sharma, V. and Sharma, S.C., Singh. S. and Sharma, R.K. (2015). Productivity enhancement in sesame (Sesamum indicum L.) as influenced by different improved production technologies. J. Oilseed Res. 32 (1): $87-90$

Malik, R.S., Sherawat, R.S., Sube, S., Loveraj, S. (2005). Relationship of farmers' trait with knowledge of rapeseed-mustard production technology. J. Oilseeds Res. 22(1):159-161

Meena B. L., Meena, R. P., Meena, R. R. and Bhim Singh (2014). Popularization of improved maize (Zea mays L.) production technology through frontline demonstrations in semi arid zone IVA of Rajasthan. J. Appl. Nat. Sci. 6 (2): 763-769

Ranawat Y., Ram, H., Sisodiya, S.S. and Punjabi, N.K. (2011). Adoption of improved maize cultivation practices by trained and untrained farmers of KVK, Udaipur. Rajasthan J. Ext. Edu. 19:144-147

Samui, S.K., Maitra, S., Roy, D.K., Mondal, A.K. and Saha, D. (2000). Evaluation of front line demonstration on groundnut (Arachis hypogea L.) in Sundarbans. J. Indian Soc. Coastal Agril. Res. 18 (2):180-183

Sharma, V., Kumar, V., Sharma, S.C. and Singh. S. (2016). Productivity enhancement and popularization of improved production technologies in wheat through frontline demonstrations. J. Appl. Nat. Sci.8 (1): 423 - 428

Singh, N. and Sharma, F.L. (2004). Impact of front line demonstration on gain in knowledge about mustard production technology among farmers. 2nd National Extension Education Congress, May 22-24, 2004. Society of Extension Education, Agra \& MPUAT, Udaipur: 56. 
Vijay Kumar et al. / J. Appl. \& Nat. Sci. 9 (1): 316 - 323 (2017)

Sreelakshmi, C.H., Sameer Kumar, C.V. and Shivani, D. (2012). Productivity enhancement of pigeon pea (Cajanus cajan L.) through improved production technology. Madras Agril. J. 99 (4-6): 248-250

Tiwari, B. K., Aashutosh Sharma, Sahare, K. V., Tripathi, P. N. and Singh, R. R. (2014). Yield gap analysis of wheat
(Triticum aestivum) through front line demonstration under limited irrigation conditions. Plant Archives 14 (1): 495-498

Tiwari, R.B., Singh, V., and Parihar, P. (2003). Role of front line demonstration in transfer of gram production technology. Maharastra J. Ext. Edu. 22 (1): 19 